\title{
Clinical Imaging Procedures and Guidelines during COVID-19 Pandemic
}

\author{
Mustafa Khaled Alhasan ${ }^{1,2 *}$ and Mohamed Hasaneen ${ }^{1}$ \\ ${ }^{1}$ Radiography and Medical Imaging Department, Fatima College of Health Sciences, \\ Abu Dhabi, UAE \\ ${ }^{2}$ Radiologic Technology Program, Applied Medical Sciences College, Jordan \\ University of Science and Technology, Jordan \\ *Corresponding Author: Mustafa Khaled Alhasan, Radiography and Medical \\ Imaging Department, Fatima College of Health Sciences, Abu Dhabi, UAE.
}

Received: June 12, 2021

Published: July 21, 2021

C) All rights are reserved by Mustafa Khaled

Alhasan and Mohamed Hasaneen.

\begin{abstract}
COVID-19 is a global pandemic that has affected almost all the world countries and spread quickly among people. Therefore, the World Health Organization (WHO) and governments have implemented strict safety protocols to stop the spread of the virus and to control the infection range. The Radiology department plays a vital role in confirming or following up with COVID-19 cases. Accordingly, guidelines and regulations were implemented to ensure staff and patients' safety and to overcome the high demand for the imaging procedures.

The purpose of this review is to highlight and address the current imaging procedures, including health and infection control guidelines applied in the radiology department. Therefore, most recent relevant articles from different databases were reviewed and summarized.

Precautionary measures including portable X-ray equipment to restrict transporting infected patients to radiology departments, utilization of personal protective equipment (PPE) and disposable gowns, and disinfecting CT, MRI gantry and ultrasound probes should be strictly implemented by radiology department personnel. During US imaging, US examiner might be at risk of getting infected due to close contact with the patient and prolonged examination time, especially with point-of-care and portable US. Regarding the radiology staff, temporal and physical team segregation strategy can be an effective way in managing radiology department workload. Therefore, maintaining the mental and physical health of staff play a critical role to implement proper health care procedures to the COVID-19 patients.
\end{abstract}

Keywords: COVID-19; Precautions; Guidelines; Radiology; CT; MRI

\section{Introduction}

Corona-viruses are groups of viruses that can affect humans and animals. The first group (229E, NL63, OC43, and KHU1) can lead to slight to moderate respiratory infections such as influenza. A severe respiratory infection can occur by the second group of the coronaviruses, including SARS-CoV and MERS-CoV. The last one on the viruses' chain is COVID-19 [1,2]. The rapid increase of the COVID-19 cases globally led to considerable changes in different life aspects. Among them, the health care system. During the pandemic, health care facilities should follow strict COVID-19 infection control policies and guidelines to sustain a sterilized environment to operate the work [3]. 
With the worsening of the COVID-19 cases worldwide, people's anxiety and fears from the virus infection increased as well. Since COVID-19 and Flu are respiratory system diseases, people start to confuse COVID-19 characteristics and symptoms with a Flu condition. However, each of them is caused by a different virus type. The spread of COVID-19 between people is faster than a Flu virus, but coronavirus symptoms require a longer time than Flu symptoms to be recognized or appear. There are some similarities and differences between the symptoms of both diseases. Common symptoms of both diseases may include chills, shortness of breath, headache, runny nose, and more. On the other hand, COVID-19 patient could experience some other symptoms such as losing smell or taste senses $[4,5]$.

COVID-19 is a global pandemic that has affected almost all the world countries, and it was spread quickly among people. Therefore, WHO and governments have implemented severe safety protocols to stop the spread of the virus and to control the infection range [3]. Moreover, CDC (The United States Centers for Disease Control and Prevention) applied prevention techniques to stop the spread of viruses. The spread of the virus can be managed by increasing the awareness of people around the world to comply with the safety guidelines [24].

Nowadays, all hospitals require imaging modalities as the primary diagnostic method. Computed Tomography (CT) is a promising imaging modality for most respiratory system diseases, including COVID-19 and Flu. In Flu cases using CT scan, axial CT images can depict the lung's consolidation and pleural thickening while COVID-19 cases using CT scan show crazy-paving sign and focal consolidation [6].

As a response to the pandemic, radiology departments announced particular policies to handle the crisis safely in order to control the spread of the virus and to apply precautions to control the department's exams. Therefore, the infection control during the COVID-19 procedure was modified to be more applicable to the current situation.

Different areas within radiology department including X-ray imaging, CT scan, magnetic resonance imaging (MRI) and ultrasound imaging (US) applied various guidelines and procedures to control patient and staff infection during COVID-19 imaging. General
X-ray and CT are the most frequent imaging modalities used for COVID-19 diagnosis and follow up. Therefore, radiology staff work in close contact with patients for positioning or bedside imaging need to strictly apply prevention and control measures. There are different gaps in the literature regarding the best safety practices within the radiology department were identified. These include the type of mask that should be used for staff safety, utilization of portable X-ray and US to reduce disease infection, staff workload and examination procedures for CT and MRI scan. Accordingly, this review aims to discuss the implemented updated COVID-19 imaging guidelines, regulations and precautions to ensure the staff and patients' safety and to overcome the high demand for the imaging procedures.

\section{WHO and general COVID-19 guidelines}

WHO intends to guide the public about COVID-19 in national and subnational levels and to update the global strategies to respond to COVID-19 pandemic. Therefore, a study was conducted to provide a short term forecast and prediction of final epidemic size. At the beginning of the epidemic in China, there was a rapid spread of the disease. After the implementation of extreme quarantine measures, the growth rate seems to be decreased. However, the model was unable to characterize the second wave dynamics of construction. This model can provide a prediction of the estimated outbreak and help countries to prepare for the pandemic [42]. Also, it can provide an insight in to the current situation, severity of the disease and symptoms in order to slow down the transmission of the disease by implementing preventive measures like rapid identification, testing and treating the patients with severe COVID-19 symptoms and implementation of isolation protocols. Moreover, implementing coordination and planning, contact tracing, providing clinical care and essential healthcare services to reduce mortality and adapt strategies based on risk and vulnerability are some of the national strategies outlined by WHO [41].

Regarding disease severity and transmission, current evidence suggests that asymptomatic and pre symptomatic patients are all capable of transmitting the virus with the incubation period ranges between 6 to 14 days. It was noted that patients older than 65 years were more prone to the severity of COVID-19 disease and men were highly susceptible to succumb to the disease. Thus, men are 2.4 times more prone than women irrespective of age and 
susceptibility [35]. In order to allocate the medical resources effectively, patient's age, gender, time interval from illness onset to diagnosis are important parameters to be analyzed. It was noted that a minimum of 19 days of hospital stay was required for patients who were below the age of 45 , while patients who were above the age of 45 stayed a bit longer; 21 days [39]. However, the hospitalization duration of patients can increase due to delirium stage. Therefore, these patients end up staying longer than the patients who do not have delirium and required increased assistance from health care professionals, and are at higher risk of nosocomial infections. Hence, it is necessary to detect the occurrence of delirium at early stages, prevent, manage and include early mobility and exercises. The main factors that may contribute to the onset of delirium include inadequate pain management, overuse of sedatives, restraints, social isolation, immobility and sleep disruption [33].

For protection purposes, protective masks can prevent splashes of biological fluids and droplets. The Advantages of using masks include reduced spread of droplets and contributing to the stopping of spread of the virus. On the other hand, disadvantages may include headaches, skin irritation, rashes, worsening acne, breathing difficulties, waste management issues and disposal problems [30]. Various studies have been conducted regarding the importance of masks in preventing transmission of infection. One of the studies conducted light scattering experiment using laser to illuminate droplets and counted them and also identified the saliva droplets that flew in to the air by the individuals who did not wear masks. By this research, it is clear that asymptomatic and pre-symptomatic individuals who do not wear masks in public can contribute to the transmission of COVID-19 and spread the infection. Accordingly, there are different types of masks intended for specific purposes. N95 masks are recommended by the WHO for health care professionals which have the ability to filter $95 \%$ of particles as small as 0.3 microns whereas homemade cloth masks which can be used by general public restricts viral particles during coughing and has 50 to $100 \%$ of efficacy of surgical masks. Therefore, by looking at the statistics, wearing masks in public prevents transmission of COVID-19 infection by people who are not showing any symptoms and are not aware that they could be carrier of the disease. Hence, wearing masks in public could be the new norm after the pandemic [37]. Additionally, WHO recommends the use of contact and droplet precautions for Healthcare workers (HCWs), protection from aerosols in procedures where there is a chance of being exposed, a risk assessment tool for HCWs who is exposed to infected patients, and also psycho-social support, adequate staffing levels and clinical rotations to prevent burn-out amongst HCWs [40].

\section{Radiology and COVID-19 guidelines}

The American College of Radiology (ACR) acknowledges the fact that radiological practices have been severely affected due the emergence and spread of the pandemic. It aims to provide general guidance to re-engage the non-emergent radiological examinations. As an accurate risk-benefit analysis of postponing radiological examination is not possible due to various reasons; specific outcome based risk of COVID-19 and outcome based risk of postponing imaging must be considered. Hence, the decision making relies on the combined approach of both referring physician and radiologist. It should outline guidelines to follow for safely performing non urgent radiological examinations. This can be used as a valuable tool to refer in other hospitals while resuming routine radiology care during COVID-19 pandemic [29].

Among these guidelines, there are different methods to reduce transmission of infection in radiology department. These include transmission based precautions by using PPE (gloves, masks, positive pressure isolation suites) and precautions introduced by CDC (Centers for Disease Control) which are combination of standard precautions and body substance fluid isolation practices, contact precautions and airborne precautions [36]. Additionally, precautionary measures to be followed by radiology department personnel include using portable X-ray equipment to restrict transporting infected patients to radiology departments, utilization of PPE, disposable gowns and disinfecting CT and MRI gantry, ultrasound probes, keyboards and mouse at the workstations after every contact with suspected patients [32].

Furthermore, health professionals need to apply standard rules to minimize the spread of the COVID-19 virus. For example, one bedspread to be used per person and wiping off the exam equipment with $2000 \mathrm{mg} / \mathrm{L}$ chlorine containing disinfectant or $75 \%$ ethanol and avoiding disinfecting the medical equipment room with spray to protect equipment from damage [18].

Regarding radiology resident safety, applying COVID-19 safety measures on the radiology resident and fellow trainees during their training program has led to several changes such as decreased need for onsite work as most of the radiologist are allowed to work 
remotely, trainees are redeployed in areas other than radiology on voluntary basis to internal medicine wards and ICUs to manage the workload of patients requiring hospitalization. The advantage of these measures is that the trainees can help fellow colleagues during this pandemic and work as a team. However, reduced number of training hours as they get to work 1 week and off for 1 week, traditional trainee- faculty member work station training has been stopped as a mean of social distancing measure, in person teaching conferences has been replaced by virtual conferences and teaching methods, research has been suspended due to laboratory closure and restricted participant visits are limitations of the applied safety measures. Additionally, postponing core examinations will lead to delay in completion of clinical scheduling and graduation which will impact the start time for fellows and incoming radiology residents. Therefore, the impact of COVID-19 has not just affected the educational aspects, it has also significantly increased psychological distress due to the pandemic and financial burden to trainees with medical school debt [26].

\section{CT scan and COVID-19 guidelines}

CT scan of the chest can be used as a supplementary tool to help in identifying the lesions. it was concluded that by keeping RT PCR test as gold standard for reference, CT chest imaging for patients with COVID-19 has a sensitivity of 99\% and hence it can be used as a tool for diagnosing patients with COVID-19. However, in children it is only $66 \%$ sensitive [34].

The specificity of CT cannot be accurately measured as it does not test a singular feature pertaining to the disease when compared to laboratory tests. Features indicative of COVID- 19 pneumonia can be found in large number of other conditions. Therefore, various national and international bodies like CDC and ACR do not recommend the use of CT as a tool to detect COVID-19. Instead, it should be used to evaluate and diagnose the complications arising from COVID-19 infection [38]. It was observed that abnormal chest imaging findings were noted, including transient areas of sub segmental consolidation with bilateral ground-glass opacities being predominant later in the course of the disease. The representation of pathology closely resembled the features of MERS and SARS. However, the overall findings are highly nonspecific and they overlap with the symptoms of influenza H1N1 or atypical pneumonia. Therefore, it should be correlated with history of contact with COVID-19 patient or recent history of travel to an eastern Asian country.
Special CT imaging procedures for COVID-19 patients were implemented to keep the standard workflow in department [7]. One of the modifications applies to the department design. The radiology department includes four areas, and each area contains different conditions. The first area is the contaminated area, which belongs to the confirmed COVID-19 patients. This area contains two rooms; one for CT exams and the other for the Digital Radiology exams. It has additional entrance to the fever area (semi-contaminated) as some patients with fever might only be suspected COVID-19 patients, which represents the second area. The third area is the buffer area specified mainly to staff preparing for exams. The fourth area is the clean area that contains reception, offices, and examination rooms. Everyone in the department, including the staff and patient, must wear a surgical mask all the time. Also, gloves, gown cuff, and eye protection, including both goggles and, face shields, are recommended. On the other hand, in the presence of suspected or confirmed COVID-19 cases, radiographers must replace the surgical mask with an N95 mask and wear disposable double gloves $[7,8]$.

Additionally, CT exam for a suspected COVID-19 patient requires transporting patients to the radiology department. In this case, more than one radiographer should be handling the case. Two of them will contact the patient through moving and positioning. Hence, they must be adequately protected by following the infection control rules. Before positioning the patient, a disposable sheet should be placed above the machine table. The next step after the exam is to clean the room and prepare for the next patient [16].

A study has described unique CT technology that can be conducted for COVID-19 patients named uVision CT. This particular procedure demonstrated effectiveness in disinfection and protection processes during the procedure. This technology can identify patients' body surfaces and set proper centers to include interesting exam areas. In this way, radiographers can communicate with patients through devices, and no need to closely contact their patients. This procedure ensures the safety of staff and patients as well [16].

\section{X-ray imaging and COVID-19 guidelines}

$\mathrm{X}$-ray is the most used modality in the radiology department, especially during the pandemic. A study reported that portable chest X-ray is the most procedure performed for ICU COVID-19 
patients [11]. On the other hand, another study showed that using new analysis techniques of the convolutional neural network can classify COVID-19 patients accurately [10]. Therefore, different countries such as China, Spain, and Italy have considered X-ray imaging as potential screening tools besides the RT-PCR for screening and administration of different patients' conditions. Accordingly, a chest X-ray (CXR) is needed using the portable X-ray unit that can be carried into the patients' rooms to minimize the interaction with patients in the imaging department $[10,11]$.

To perform an X-ray exam for suspected patients, staff should apply infection control rules before, during, and after the exam. A portable machine can perform X-ray exams to avoid moving patients from one place over another to reduce the risk of spreading the infection. Therefore, portable X-ray machines are allocated for the isolation units, and disposable covers are provided for the imaging detectors. The examination room must be prepared with all the necessary equipment [3].

\section{US imaging and COVID-19 guidelines}

COVID-19 in pregnancy needs a framework that can be followed by the maternity centers managing pregnant patients during pandemic and ensuring safety of the patient and health care workers. Physiological susceptibility of cardiovascular system and immune system is elaborated by mentioning different types of infections and risks they are prone to. Probability of pregnant patient to acquire these pathology is higher as they are considered as vulnerable group [28]. The ultrasound (US) scan plays a vital role in the current pandemic especially for pregnancy examinations. The whole process requires the radiology department staff's cooperation to manage imaging the patients by applying the COVID-19 safety strategies in the radiology department [13].

This exam can be safe for pregnancy tests and also be operated by a portable machine. After performing the exam, the room should be cleaned very well, and sonographers should wash their hands before and after leaving the room. However, US examiner might be at risk of getting infected due to close contact with the patient and prolonged examination time, especially with point-of-care and portable US [12].

\section{MRI imaging and COVID-19 guidelines}

MRI examination of COVID-19 infection-control regulations cover five aspects as requirements for the MRI scan including MRI room design, pre-admission, preparation of medical staff and patients and finally disinfection after MRI examination [14]. MRI for suspected COVID-19 patients, requires help from the infection control team to move a patient in and out of the department safely. After performing the MRI exam, the room should be cleaned by expert staff in dealing with high magnetic field areas. As a result, High Efficiency Particulate Air (HEPA) filter should be used to exchange the air before the next patient. By following these steps, the room will be decontaminated and ready for the subsequent examination [15].

\section{Interventional radiology and COVID-19 guidelines}

For interventional procedures, fixed and essential contact surfaces within the room should be covered with a clean sterile cover. Moreover, Careful hand hygiene, the correct wearing of protective equipment, N95 or FFP2 masks and eye protection, gowns, gloves, aprons, and shoe covers are recommended, and used personal protective equipment (PPE) must be collected in dedicated disposal bags $[7,17]$. Additionally, in order to reduce intra institutional spread of SARS COV-2 and COVID-19, some procedures need to be followed in interventional radiology department during the COVID-19 pandemic including segregation of patients and decentralization of services in response to nosocomial transmission of infection, mandatory RT PCR testing for all patients and health care workers to identify infected patients and staffs, designating separate routes for isolated patients so that they do not use the conventional routes, limiting the presence of number of staffs who are not directly involved in the procedures and eliminating non-essential equipment from the room and training staffs adequately to follow the guidelines listed by the WHO for using PPE and N95 masks. By following such rigorous guidelines, there was no cross infection documented in their hospital. However, it did increase the cost of the equipment and the procedure time [25].

Moreover, there is a high incidence and severity of complications associated with patients undergoing surgery who were unknown to be carriers of the disease, or were infected after the procedure. The most logical and simple way to handle this is by cancelling all elective procedures unless deemed urgent, maintaining social distancing, carrying out immunoglobulin $\mathrm{M}$ and immunoglobulin $\mathrm{G}$ in the first appointment, and a second test must be repeated after 7 days, in addition to a PCR test and isolating patient for 7 days before the surgery [27]. Accordingly, coordination between staff, 
handling patients, preparation of staff and interventional suite before the arrival of patients and after finishing the procedure, and improving the facility ventilation systems are crucial steps [25].

\section{Staff workload and COVID-19 guidelines}

A study has indicated that the medical staff are considered the frontline of fighting COVID-19 and focused on following the safety protocols in the X-ray department as they examine COVID-19 suspected patients. Also, they have to examine other patients daily with other different diseases [18]. Likewise, a study has discussed the dynamic department process and the management role for supporting the radiology staff to achieve sufficient capacity during such crisis [19]. Besides, radiographers, nurses, and other staff in the radiology department must demonstrate an acceptable knowledge level about applying protection control methods during the procedures $[7,19]$.

Radiographers who work with COVID-19 patients may face a lot of stress and pressure. Therefore, re-scheduling duty timing and providing longer break time are suggested to ensure readiness to continue the duty. COVID-19 affects the workflow in radiology departments; for example, for the patients' waiting area, the pandemic decreases the waiting area capacity to comply with the patient's social distancing. The frequency of the examinations is also reduced and the working hours are extended to cover the work overload. However, applying longer working hours will facilitate the room's cleaning and preparation procedures for the next patient. For COVID-19 suspected patient's imaging, two radiographers must conduct the procedure. The First radiographer has to comply with safety measures and apply the procedure. The preparation includes double gloves, gown cuff, and N95 mask with a face shield, positioning the patient and cleaning the equipment after scanning. The second radiographer has to conduct the scanning in the control console room $[8,9]$.

Therefore, hospitals may have to increase the number of workers and train them. Accordingly, some hospitals follow segregation strategy by forming a team with different skills, including radiologists, radiographers, and nurses. Team segregation is divided into temporal and physical strategies. For temporal segregation, sometimes anyone from the staff can have the infection without any symptoms, which will lead to spreading the virus between the staff during the incubation period of COVD-19 (14 days). Therefore, an exchange occurs at the end of the $2^{\text {nd }}$ week period between the team groups. One group is working for two weeks cautiously, and the other group is self-quarantined at home. However, this strategy faces many problems since hospitals cannot tolerate too many quarantine staffs. The other issue is working at this level of risk for 14 consecutive days may be mentally and physically overwhelming for the staff. On the other hand, physical segregation is to split staff between hospitals and to complete their work in the selected hospital to avoid viral transition across hospitals. Furthermore, staff like radiologists can have the ability to control their workstation remotely from their homes, unlike radiographers and nurses who are required to be present in person [8]. Additionally, hospitals worldwide facing COVID-19 have increased the number of portable machines in every emergency department (ER) since the beginning of the outbreak and equipped with outdoor tents ready to deal with infected patients to control disease transmission $[7,8]$.

\section{Strategies to maintain COVID-19 guidelines}

There are several strategies can help hospitals to control COVID-19 pandemic. Firstly, by conducting awareness sessions about infection prevention techniques such as social distancing, handwashing, and sanitizing methods, and reviewing the practice protocols for decontaminating imaging rooms after dealing with COVID-19 patients [19]. Secondly, when dealing with COVID-19 patients, staff need to have PPE, surgical cap, gloves, N95 mask, medical protective clothing, goggles, and face shield readily available. A special infection control procedure must be performed on the equipment as well [7]. Thirdly, reducing staff traffic and gathering in all departments is recommended. Fourthly, staff stress relief can play an essential role in the quality of work by encouraging staff to have adequate sleep and rest [20].

Maintaining the mental and physical health of staff play a critical role to implement proper health care procedure to the COVID-19 patients. Their family concerns and fears about viral transmission require more attention by enhancing the service's and preventing infection. The working environment can be improved by including room for staff supplied with food, beds, and furniture to rest in a quiet place. Likewise, using calling applications to communicate with their families, such as Teams software, is helpful. Therefore, there is a significant demand on the radiology services that requires appropriate preparedness rules and guidelines to overcome a large number of COVID-19 cases and to ensure the safety of the staff [21-23]. 
Additionally, physical activities play an important role in reducing the symptoms of depression, stress and improved concentration. Regular physical activities can result in better cardiovascular health, increased immunity and endurance and strengthening respiratory muscles. WHO recommends some simple home based exercises that can be followed during the lockdown which can be easily followed to keep ourselves active. Performing household chores also results in energy expenditure. Importance of regular interruptions from prolonged sitting time is encouraged in order to regulate metabolic health ${ }^{31}$. The included articles are summarized in table 1.

\begin{tabular}{|c|c|c|c|c|c|c|}
\hline $\begin{array}{l}\text { Author name and } \\
\text { article number in } \\
\text { the references list }\end{array}$ & Study title & Country & $\begin{array}{l}\text { Study } \\
\text { type }\end{array}$ & Study aims & Data type & Key findings \\
\hline An P., et al. [18] & $\begin{array}{c}\text { Management } \\
\text { strategy of } \\
\text { novel coronavi- } \\
\text { rus (COVID-19) } \\
\text { pneumonia in } \\
\text { the radiology } \\
\text { department: a } \\
\text { Chinese experi- } \\
\text { ence. }\end{array}$ & China & $\begin{array}{l}\text { Commu- } \\
\text { nication } \\
\text { study }\end{array}$ & $\begin{array}{c}\text { Aspects of CT acquisi- } \\
\text { tion process, protec- } \\
\text { tion level, equipment } \\
\text { management. }\end{array}$ & Guidelines & $\begin{array}{c}\text { It is necessary to determine practical, } \\
\text { efficient and feasible prevention and } \\
\text { control measures to prevent and control } \\
\text { the spread of COVID-19 in the radiology } \\
\text { departments. } \\
\text { To complete the radiology examination } \\
\text { safely and diagnose COVID-19 pneu- } \\
\text { monia patients with high efficiency and } \\
\text { quality. }\end{array}$ \\
\hline $\begin{array}{l}\text { Ierardi AM., et al. } \\
{[25]}\end{array}$ & $\begin{array}{c}\text { How to handle } \\
\text { a COVID-19 } \\
\text { Patient in the } \\
\text { Angiographic } \\
\text { Suite. }\end{array}$ & Italy & $\begin{array}{l}\text { Report } \\
\text { study }\end{array}$ & $\begin{array}{c}\text { The precautions to } \\
\text { control the spread of } \\
\text { COVID-19 within the } \\
\text { healthcare facility. }\end{array}$ & Guidelines & $\begin{array}{c}\text { Control measures are to minimize intra- } \\
\text { institutional spread of SARS-CoV-2 and } \\
\text { COVID-19. } \\
\text { Pre-, intra- and post-procedural ap- } \\
\text { proaches for IR workflow described in } \\
\text { the setting of an IR unit highly exposed } \\
\text { to COVID-19. }\end{array}$ \\
\hline Ashari MA., et al. [3] & $\begin{array}{c}\text { Strategies } \\
\text { for radiology } \\
\text { departments } \\
\text { in handling } \\
\text { the COVID-19 } \\
\text { pandemic. }\end{array}$ & Malaysia & $\begin{array}{l}\text { Report } \\
\text { Study }\end{array}$ & $\begin{array}{c}\text { Strategies to improve } \\
\text { preparedness, and } \\
\text { response towards the } \\
\text { pandemic in the radi- } \\
\text { ology department }\end{array}$ & Guidelines & \begin{tabular}{|} 
To form a centralized task force at the \\
department level to construct policies \\
and strategies in liaison with institu- \\
tional and international guidelines. \\
Rational and proper usage of personal \\
protective equipment, especially by \\
frontline staff, reduces the risk of noso- \\
comial spread. \\
Proactive human resource management \\
is crucial to ensure services continue at \\
optimal capacity.
\end{tabular} \\
\hline
\end{tabular}




\begin{tabular}{|c|c|c|c|c|c|c|}
\hline Backer JA., et al. [2] & $\begin{array}{c}\text { Incubation } \\
\text { period of } 2019 \\
\text { novel corona- } \\
\text { virus (2019- } \\
\text { nCoV) infec- } \\
\text { tions among } \\
\text { travelers from } \\
\text { Wuhan, China, } \\
20-28 \text { January } \\
2020 .\end{array}$ & $\begin{array}{l}\text { Nether- } \\
\text { lands }\end{array}$ & $\begin{array}{c}\text { Analytical } \\
\text { study }\end{array}$ & \begin{tabular}{|} 
Distribution of \\
incubation periods \\
estimated for travel- \\
ers from Wuhan with \\
confirmed 2019- \\
nCoV infection in the \\
early outbreak phase
\end{tabular} & $\begin{array}{l}\text { The data used } \\
\text { for this analy- } \\
\text { sis has been } \\
\text { translated } \\
\text { from Chinese } \\
\text { sources such } \\
\text { as provincial } \\
\text { center of dis- } \\
\text { ease control. }\end{array}$ & $\begin{array}{c}\text { Incubation period distribution is } \\
\text { required to determine the appropriate } \\
\text { duration of quarantine. } \\
\text { Knowledge of the incubation period } \\
\text { helps to assess the effectiveness of entry } \\
\text { screening and contact tracing. } \\
88 \text { confirmed cases gave an estimated } \\
\text { incubation period for Coronavirus, } \\
\text { which helps in identifying the virus and } \\
\text { the appropriate quarantine durations. }\end{array}$ \\
\hline $\begin{array}{l}\text { Cárdenas Camarena } \\
\text { L., et al. [27] }\end{array}$ & \begin{tabular}{|} 
Elective Surgery \\
during SARs- \\
Cov-2/COV- \\
ID-19 Pandemic \\
safety protocols \\
with literature \\
review.
\end{tabular} & Mexico & $\begin{array}{c}\text { Literature } \\
\text { review }\end{array}$ & $\begin{array}{l}\text { Reduce the effect of } \\
\text { infection of SARs- } \\
\text { Cov-2/COVID-19 in } \\
\text { hospitals. }\end{array}$ & $\begin{array}{c}\text { Reviewed } \\
105 \text { ar- } \\
\text { ticles and } 60 \\
\text { selected for } \\
\text { analysis. }\end{array}$ & $\begin{array}{c}\text { Although RT-PCR and Ab tests indicated } \\
\text { for COVID-19 diagnosis, there will al- } \\
\text { ways be a } 10 \% \text { chance that those might } \\
\text { not detect an actual infected patient. } \\
\text { Avoid including patients with comor- } \\
\text { bidities that could worsen the COVID-19 } \\
\text { infection. } \\
\text { Implementation of prevention and con- } \\
\text { trol strict measures in each health care } \\
\text { facility where surgeries are scheduled. }\end{array}$ \\
\hline CDC [24] & $\begin{array}{l}\text { Things to } \\
\text { know about } \\
\text { the COVID-19 } \\
\text { pandemic. }\end{array}$ & USA & $\begin{array}{c}\text { CDC } \\
\text { guidelines }\end{array}$ & $\begin{array}{l}\text { COVID-19 informa- } \\
\text { tion and prevention } \\
\text { protocols }\end{array}$ & $\begin{array}{l}\text { Public infor- } \\
\text { mation from } \\
\text { CDC }\end{array}$ & $\begin{array}{l}\text { Comply with precautions to prevent the } \\
\text { spread of the virus. }\end{array}$ \\
\hline $\begin{array}{l}\text { Chaudhry FB., et al. } \\
{[21]}\end{array}$ & $\begin{array}{l}\text { COVID-19: } \\
\text { Frontline } \\
\text { experience at } \\
\text { a tertiary care } \\
\text { hospital in UK. }\end{array}$ & UK & $\begin{array}{l}\text { Report } \\
\text { study }\end{array}$ & $\begin{array}{l}\text { Understand the huge } \\
\text { effort of the frontline } \\
\text { in the hospital during } \\
\text { the COVID-19 break- } \\
\text { out in the UK. }\end{array}$ & $\begin{array}{c}\text { Frontline } \\
\text { experience }\end{array}$ & $\begin{array}{c}\text { To support the medical frontline due to } \\
\text { the massive stress and efforts during the } \\
\text { crises. } \\
\text { Psychological impact of the pandemic } \\
\text { on staff and suggested strategies. }\end{array}$ \\
\hline $\begin{array}{l}\text { Dashraath P., et al. } \\
{[28]}\end{array}$ & $\begin{array}{c}\text { Coronavi- } \\
\text { rus disease } \\
2019(\mathrm{CO}- \\
\text { VID-19) } \\
\text { pandemic and } \\
\text { pregnancy. }\end{array}$ & Singapore & $\begin{array}{c}\text { Literature } \\
\text { review }\end{array}$ & $\begin{array}{l}\text { The clinical features } \\
\text { of pregnant women } \\
\text { with COVID-19, and } \\
\text { a pragmatic and in- } \\
\text { tegrated framework } \\
\text { that addresses the } \\
\text { obstetric complexi- } \\
\text { ties of managing this } \\
\text { disease in pregnancy. }\end{array}$ & $\begin{array}{l}\text { A review of } \\
\text { COVID-19 in } \\
\text { pregnancy. } \\
\text { Details of } \\
\text { Data not } \\
\text { mentioned }\end{array}$ & $\begin{array}{l}\text { The role of the equipment protection } \\
\text { and protocols decreases the spread of } \\
\text { COVID-19. } \\
\text { Antiviral therapy and vaccine develop- } \\
\text { ment, including the novel use of chloro- } \\
\text { quine in the management of COVID-19. } \\
\text { Special precautions are required to } \\
\text { minimize cross-infection of healthcare } \\
\text { providers while performing procedures. }\end{array}$ \\
\hline
\end{tabular}




\begin{tabular}{|c|c|c|c|c|c|c|}
\hline $\begin{array}{l}\text { Davenport MS., et al. } \\
\text { [29] }\end{array}$ & \begin{tabular}{|} 
ACR Statement \\
on safe resump- \\
tion of Routine \\
radiology care \\
during the \\
coronavirus \\
disease 2019 \\
(COVID-19) \\
pandemic.
\end{tabular} & USA & $\begin{array}{l}\text { Report } \\
\text { Study }\end{array}$ & $\begin{array}{l}\text { Radiology protocols } \\
\text { during COVID-19 in } \\
\text { the US. }\end{array}$ & Guidelines & $\begin{array}{l}\text { Guidelines and routine procedures are } \\
\text { applied for COVID-19 care in Radiology. } \\
\text { Strategy for the safe resumption of rou- } \\
\text { tine radiology care during the COVID-19 } \\
\text { pandemic. }\end{array}$ \\
\hline Ding J., et al. [9] & $\begin{array}{l}\text { Prevention and } \\
\text { control measure } \\
\text { in radiology } \\
\text { department for } \\
\text { COVID-19 }\end{array}$ & China & $\begin{array}{l}\text { Report } \\
\text { Study }\end{array}$ & $\begin{array}{c}\text { Guidelines control } \\
\text { measures, and pre- } \\
\text { vention of the spread } \\
\text { of COVID-19 in Radi- } \\
\text { ology Department. }\end{array}$ & Guidelines & $\begin{array}{c}\text { The novel coronavirus spreads rapidly } \\
\text { through droplet and contact transmis- } \\
\text { sion. } \\
\text { Radiologists and technologists were } \\
\text { possibly infected by patients. } \\
\text { Prevention and control measures in } \\
\text { radiology department for COVID-19 are } \\
\text { important. }\end{array}$ \\
\hline $\begin{array}{l}\text { Ertl Wagner BB., et } \\
\text { al. [22] }\end{array}$ & $\begin{array}{l}\text { Preparedness } \\
\text { for the COV- } \\
\text { ID-19 pandemic } \\
\text { in a tertiary } \\
\text { pediatric radiol- } \\
\text { ogy depart- } \\
\text { ment. }\end{array}$ & Canada & $\begin{array}{c}\text { Analytical } \\
\text { study }\end{array}$ & $\begin{array}{l}\text { The importance of } \\
\text { preparation for the } \\
\text { radiology depart- } \\
\text { ments to cope with } \\
\text { the changes with } \\
\text { COVID-19. }\end{array}$ & Guidelines & $\begin{array}{l}\text { To evaluate the current situation and } \\
\text { cope with challenges. } \\
\text { Description and analysis of current } \\
\text { processes as basis for discussion for } \\
\text { pediatric radiology departments. }\end{array}$ \\
\hline Gogna A., et al. [12] & $\begin{array}{l}\text { Diagnostic } \\
\text { Ultrasound } \\
\text { Services Dur- } \\
\text { ing Corona- } \\
\text { virus Disease } \\
\text { (COVID-19) } \\
\text { Pandemic. }\end{array}$ & Singapore & $\begin{array}{l}\text { Report } \\
\text { study }\end{array}$ & $\begin{array}{c}\text { The protocols that } \\
\text { increase the qual- } \\
\text { ity of Ultrasound } \\
\text { department services } \\
\text { during the outbreak } \\
\text { of COVID-19 }\end{array}$ & Guidelines & $\begin{array}{l}\text { The Ultrasound service providers } \\
\text { should comply with the strategies of CO- } \\
\text { VID-19 prevention as they are frontline } \\
\text { fighters. } \\
\text { Diagnostic US protocol for effective } \\
\text { service provision, staff protection, and } \\
\text { business continuity planning }\end{array}$ \\
\hline
\end{tabular}




\begin{tabular}{|c|c|c|c|c|c|c|}
\hline Huang Z., et al. [7] & $\begin{array}{c}\text { The Battle } \\
\text { against } \\
\text { Coronavirus } \\
\text { Disease 2019 } \\
\text { (COVID-19): } \\
\text { Emergency } \\
\text { Management } \\
\text { and infection } \\
\text { Control in Radi- } \\
\text { ology Depart- } \\
\text { ment. }\end{array}$ & China & $\begin{array}{l}\text { Report } \\
\text { Study }\end{array}$ & $\begin{array}{l}\text { Strategy, emergency } \\
\text { management and } \\
\text { infection control pro- } \\
\text { cedure for radiology }\end{array}$ & Guidelines & $\begin{array}{l}\text { Reconfiguration of the Radiology de- } \\
\text { partment. } \\
\text { Equipment disinfection procedures. } \\
\text { The prevention strategies resulted in } \\
\text { none of the radiology staff infected by } \\
\text { COVID-19 infection. }\end{array}$ \\
\hline Khan SH., et al. [10] & \begin{tabular}{|c} 
Coronavirus \\
Disease Analy- \\
sis using Chest \\
X-ray Images \\
and Novel Deep \\
Convolutional \\
Neural Net- \\
work.
\end{tabular} & Pakistan & $\begin{array}{c}\text { Analytical } \\
\text { study }\end{array}$ & $\begin{array}{c}\text { The role of Chest } \\
\text { X-ray to diagnose } \\
\text { COVID-19 in order to } \\
\text { control the outbreak } \\
\text { of the virus. }\end{array}$ & $\begin{array}{l}\text { Images col- } \\
\text { lected from } \\
\text { Pakistan } \\
\text { Higher Edu- } \\
\text { cation. }\end{array}$ & $\begin{array}{c}\text { The analysis model provides additional } \\
\text { help in patient classification. }\end{array}$ \\
\hline WHO [30] & $\begin{array}{l}\text { Rational use } \\
\text { of personal } \\
\text { protective } \\
\text { equipment for } \\
\text { coronavirus } \\
\text { disease 2019 } \\
\text { (COVID-19) } \\
\end{array}$ & $\begin{array}{l}\text { World } \\
\text { Health } \\
\text { Organiza- } \\
\text { tion }\end{array}$ & $\begin{array}{c}\text { WHO } \\
\text { guidance } \\
\text { report. }\end{array}$ & $\begin{array}{l}\text { Information about } \\
\text { PPE }\end{array}$ & $\begin{array}{l}\text { Public article } \\
\text { for PPE }\end{array}$ & $\begin{array}{c}\text { Preventive measures for COVID-19. } \\
\text { Optimizing the availability of PPE. } \\
\text { Responders must be trained on the use } \\
\text { of PPE. }\end{array}$ \\
\hline $\begin{array}{l}\text { Jakobsson J., et al. } \\
{[31]}\end{array}$ & $\begin{array}{l}\text { Physical Activ- } \\
\text { ity During the } \\
\text { Coronavirus } \\
\text { (COVID-19) } \\
\text { Pandemic: } \\
\text { Prevention of } \\
\text { a Decline in } \\
\text { Metabolic and } \\
\text { Immunological } \\
\text { Functions } \\
\end{array}$ & $\begin{array}{c}\text { Sweden } \\
\text { and Nor- } \\
\text { way }\end{array}$ & $\begin{array}{l}\text { Review } \\
\text { study }\end{array}$ & $\begin{array}{l}\text { Prevention meth- } \\
\text { ods for the Immune } \\
\text { system. }\end{array}$ & $\begin{array}{c}\text { Selected } \\
\text { articles were } \\
\text { reviewed. }\end{array}$ & $\begin{array}{l}\text { To follow the prevention methods to } \\
\text { avoid infection and complications of } \\
\text { COVID-19. } \\
\text { Interrupt prolonged sitting time and } \\
\text { reduce sedentariness. } \\
\text { Muscle-strengthening and cardiovascu- } \\
\text { lar exercises. }\end{array}$ \\
\hline Kooraki S., et al. [32] & $\begin{array}{c}\text { Coronavirus } \\
\text { (COVID-19) } \\
\text { Outbreak: What } \\
\text { the Department } \\
\text { of Radiology } \\
\text { should know. }\end{array}$ & USA & $\begin{array}{c}\text { Review } \\
\text { study }\end{array}$ & $\begin{array}{l}\text { Discuss the epide- } \\
\text { miology and the } \\
\text { imaging results of the } \\
\text { symptoms of corona- } \\
\text { virus. }\end{array}$ & $\begin{array}{c}\text { Selected } \\
\text { articles were } \\
\text { reviewed. }\end{array}$ & $\begin{array}{l}\text { The radiology department should follow } \\
\text { the prevention procedures to stop the } \\
\text { virus's spread. } \\
\text { Precautions and safety measures for } \\
\text { radiology department personnel to } \\
\text { manage patients. }\end{array}$ \\
\hline LaHue SC., et al. [33] & $\begin{array}{l}\text { Collabora- } \\
\text { tive Delirium } \\
\text { Prevention } \\
\text { in the Age of } \\
\text { COVID-19. }\end{array}$ & USA & $\begin{array}{l}\text { Report } \\
\text { study }\end{array}$ & $\begin{array}{c}\text { How to ensure the } \\
\text { health of a patient } \\
\text { with delirium during } \\
\text { COVID-19. }\end{array}$ & Guidelines & $\begin{array}{l}\text { Recommendations for minimizing the } \\
\text { risk and duration of delirium in all pa- } \\
\text { tients during the COVID-19 pandemic. } \\
\text { Integrate technology into the workflow } \\
\text { to reduce the isolation felt between } \\
\text { patients and family members. }\end{array}$ \\
\hline
\end{tabular}




\begin{tabular}{|c|c|c|c|c|c|c|}
\hline Liang Y., et al. [20] & $\begin{array}{c}\text { Screening for } \\
\text { Chinese medical } \\
\text { staff mental } \\
\text { health by SDS } \\
\text { and SAS during } \\
\text { the outbreak of } \\
\text { COVID-19 }\end{array}$ & China & $\begin{array}{c}\text { Clinical } \\
\text { study }\end{array}$ & $\begin{array}{l}\text { Assessing the mental } \\
\text { health of frontline } \\
\text { staff. }\end{array}$ & \begin{tabular}{|} 
SDS and SAS \\
raw scores \\
of 23 doc- \\
tors and 36 \\
nurses from \\
COVID-19 \\
associated \\
departments \\
(38 par- \\
ticipants) and \\
others (21 \\
participants).
\end{tabular} & $\begin{array}{l}\text { Adequate resting for medical staff can } \\
\text { relieve the stress. } \\
\text { Essential for medical staff to keep physi- } \\
\text { cal and psychological health during our } \\
\text { struggle of COVID-19. } \\
\text { SDS and SAS were simple tools to moni- } \\
\text { toring the self-mental health. }\end{array}$ \\
\hline Lv M., et al. [34] & $\begin{array}{l}\text { Chest computed } \\
\text { Tomography for } \\
\text { the diagnosis } \\
\text { of patients with } \\
\text { Coronavirus } \\
\text { Disease 2019: } \\
\text { A rapid Review } \\
\text { and Meta-Anal- } \\
\text { ysis }\end{array}$ & China & $\begin{array}{c}\text { Review } \\
\text { Study }\end{array}$ & $\begin{array}{c}\text { Role of CT for the di- } \\
\text { agnosis and the main } \\
\text { imaging manifesta- } \\
\text { tions of patients with } \\
\text { COVID-19. }\end{array}$ & $\begin{array}{l}103 \text { studies } \\
\text { with a total of } \\
5,673 \text { partici- } \\
\text { pants were } \\
\text { eligible for } \\
\text { inclusion. }\end{array}$ & $\begin{array}{l}\text { The meta- analysis review illustrates } \\
\text { the effectiveness of chest CT to diagnose } \\
\text { COVID-19 cases. } \\
\text { The sensitivity of chest CT scan in CO- } \\
\text { VID-19 is } 99 \% \\
\text { Common imaging manifestation of } \\
\text { patients infected with SARS-CoV-2 was } \\
\text { GGO with bilateral peripheral distribu- } \\
\text { tion. }\end{array}$ \\
\hline Jin JM., et al. [35] & $\begin{array}{c}\text { Gender dif- } \\
\text { ferences in } \\
\text { patients with } \\
\text { COVID-19: focus } \\
\text { on severity and } \\
\text { mortality }\end{array}$ & China & $\begin{array}{l}\text { Clinical } \\
\text { Study. }\end{array}$ & $\begin{array}{c}\text { To compare the } \\
\text { severity and mortal- } \\
\text { ity between male and } \\
\text { female patients with } \\
\text { COVID-19 or SARS. }\end{array}$ & \begin{tabular}{|c|}
43 hospital- \\
ized patients, \\
37 cases \\
of patients \\
who died of \\
COVID-19 \\
and 1,019 \\
patients who \\
survived in \\
China, and \\
data of 524 \\
patients \\
with SARS, \\
including 139 \\
deaths, from \\
Beijing in \\
early 2003.
\end{tabular} & \begin{tabular}{|} 
Coronavirus is a large family of viruses \\
that cause illnesses ranging from the \\
common cold to severe pneumonia, such \\
as SARS, and Middle East Respiratory \\
Syndrome (MERS) \\
Men with COVID-19 are at higher risk of \\
death than women. \\
Gender is a risk factor for higher \\
severity and mortality in patients with \\
COVID-19, independent of age and \\
susceptibility.
\end{tabular} \\
\hline Saudi MOH [15] & $\begin{array}{l}\text { Radiology De- } \\
\text { partment pre- } \\
\text { paredness plan } \\
\text { for COVID-19. }\end{array}$ & $\begin{array}{c}\text { Saudi } \\
\text { Arabia }\end{array}$ & $\begin{array}{l}\text { Policies } \\
\text { and pro- } \\
\text { cedures }\end{array}$ & $\begin{array}{c}\text { List of the policies } \\
\text { and professional ra- } \\
\text { diological services. }\end{array}$ & Guidelines & $\begin{array}{l}\text { The radiologist should follow the } \\
\text { policies when investigating COVID-19 } \\
\text { known/suspected patients to prevent } \\
\text { the virus spread. }\end{array}$ \\
\hline
\end{tabular}




\begin{tabular}{|c|c|c|c|c|c|c|}
\hline Mirza SK., et al. [36] & $\begin{array}{c}\text { Microbiology } \\
\text { for radiologists: } \\
\text { How to mini- } \\
\text { mize infection } \\
\text { transmission in } \\
\text { the radiology } \\
\text { department. }\end{array}$ & USA & $\begin{array}{l}\text { Report } \\
\text { Study }\end{array}$ & $\begin{array}{c}\text { Ways of transmis- } \\
\text { sion of infection-to } \\
\text { prevent spread to the } \\
\text { radiology staff. }\end{array}$ & Guidelines & $\begin{array}{l}\text { Routes of Disease Transmission. } \\
\text { Transmission based precautions. } \\
\text { Safe handling of specimens. }\end{array}$ \\
\hline $\begin{array}{l}\text { Basha MM., et al. } \\
{[19]}\end{array}$ & \begin{tabular}{|} 
Radiol- \\
ogy department \\
preparedness \\
for COVID-19: \\
Radiology \\
Scientific expert \\
reviews panel.
\end{tabular} & USA & $\begin{array}{l}\text { Report } \\
\text { study }\end{array}$ & $\begin{array}{c}\text { Priorities for CO- } \\
\text { VID-19 preparedness } \\
\text { in different hospitals. }\end{array}$ & Guidelines & $\begin{array}{c}\text { To achieve sufficient capacity for con- } \\
\text { tinued operation during a health care } \\
\text { emergency of unprecedented propor- } \\
\text { tions. } \\
\text { To support the care of patients with } \\
\text { COVID-19. } \\
\text { To maintain radiologic diagnostic and } \\
\text { interventional support for the entirety } \\
\text { of the hospital and health system. }\end{array}$ \\
\hline Pan W., et al. [23] & $\begin{array}{l}\text { Mental state of } \\
\text { central sterile } \\
\text { supply depart- } \\
\text { ment staff dur- } \\
\text { ing COVID-19. }\end{array}$ & China & $\begin{array}{l}\text { Survey } \\
\text { study }\end{array}$ & $\begin{array}{l}\text { Lists the factors that } \\
\text { affect the general } \\
\text { mental health during } \\
\text { the COVID-19 crises } \\
\text { in China. }\end{array}$ & \begin{tabular}{|c|}
423 CSSD \\
staff mem- \\
bers from 35 \\
Secondary \\
A or above \\
hospitals in \\
Sichuan Prov- \\
ince, China. \\
423 question- \\
naires were \\
distributed, \\
and 423 valid \\
question- \\
naires were \\
returned.
\end{tabular} & $\begin{array}{l}\text { Factors for resilience, perceived stress, } \\
\text { and anxiety for CSSD staff. } \\
\text { The medical staff was under massive } \\
\text { stress during the COVID-19, which } \\
\text { required mental health attention. } \\
\text { CSSD staff was at risk of being infected } \\
\text { with the novel coronavirus through oc- } \\
\text { cupational exposure }\end{array}$ \\
\hline Qu J., et al. [16] & $\begin{array}{c}\text { Infection } \\
\text { control for CT } \\
\text { equipment and } \\
\text { Radiographers' } \\
\text { personal pro- } \\
\text { tection during } \\
\text { the coronavi- } \\
\text { rus Disease } \\
\text { (COVID-19) } \\
\text { Outbreak in } \\
\text { China. }\end{array}$ & China & $\begin{array}{l}\text { Report } \\
\text { study }\end{array}$ & $\begin{array}{c}\text { Investigate the infec- } \\
\text { tion prevention and } \\
\text { control management } \\
\text { of CT }\end{array}$ & Guidelines & $\begin{array}{l}\text { Modifications to the CT examination } \\
\text { process, including disinfection protocol } \\
\text { to enhance the overall imaging. } \\
\text { Disinfection of CT Examination rooms. } \\
\text { Personal protection of radiographers. }\end{array}$ \\
\hline Rab S., et al. [37] & $\begin{array}{c}\text { Face masks are } \\
\text { new normal } \\
\text { after COVID-19 } \\
\text { pandemic. }\end{array}$ & India & $\begin{array}{c}\text { Letter to } \\
\text { the Editor }\end{array}$ & \begin{tabular}{|} 
Highlight the im- \\
portance of wearing \\
masks in different \\
countries
\end{tabular} & Guidelines & $\begin{array}{l}\text { Wearing masks will be expected after } \\
\text { the COVID-19 pandemic. } \\
\text { Medical or homemade masks for general } \\
\text { public use and N95 masks for health } \\
\text { care professionals are suggested by } \\
\text { WHO. } \\
\text { Mask-wearing in a public place seems } \\
\text { one of the most effective ways to stop } \\
\text { the spread of the virus when compliance } \\
\text { is high. }\end{array}$ \\
\hline
\end{tabular}




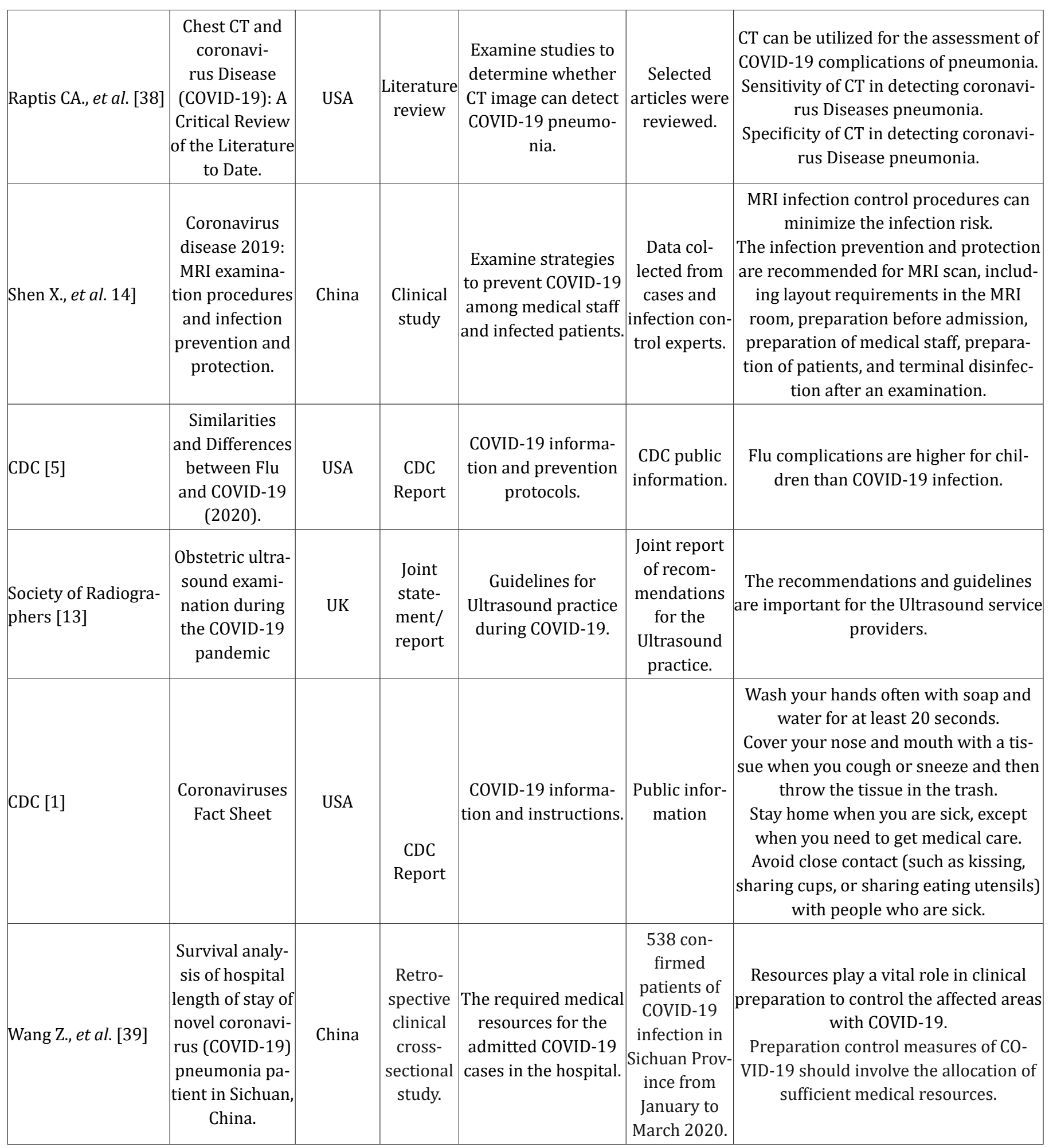




\begin{tabular}{|c|c|c|c|c|c|c|}
\hline WHO [40] & $\begin{array}{c}\text { Coronavirus } \\
\text { disease } 2019 \\
\text { (COVID-19) } \\
\text { Situation Re- } \\
\text { port - } 82\end{array}$ & $\begin{array}{l}\text { World } \\
\text { Health } \\
\text { Organiza- } \\
\quad \text { tion }\end{array}$ & $\begin{array}{l}\text { WHO } \\
\text { report }\end{array}$ & $\begin{array}{l}\text { Report on the recent } \\
\text { COVID-19 statistics. }\end{array}$ & $\begin{array}{l}\text { WHO public } \\
\text { report of } \\
\text { COVID-19. }\end{array}$ & Cases statistics of different countries. \\
\hline WHO [41] & $\begin{array}{l}\text { COVID-19 strat- } \\
\text { egy update. }\end{array}$ & $\begin{array}{l}\text { World } \\
\text { Health } \\
\text { Organiza- } \\
\text { tion }\end{array}$ & $\begin{array}{l}\text { WHO } \\
\text { report }\end{array}$ & $\begin{array}{l}\text { Describe the CO- } \\
\text { VID-19 update strate- } \\
\text { gies in the world. }\end{array}$ & $\begin{array}{l}\text { WHO public } \\
\text { report. }\end{array}$ & $\begin{array}{l}\text { COVID-19 invaded the world and af- } \\
\text { fected the socioeconomic status. }\end{array}$ \\
\hline Wu K., et al. 42] & $\begin{array}{c}\text { Generalized } \\
\text { logistic growth } \\
\text { modeling of } \\
\text { COVID-19 } \\
\text { outbreak: } \\
\text { comparing the } \\
\text { dynamic in the } \\
29 \text { provinces } \\
\text { in China and in } \\
\text { the rest of the } \\
\text { world. }\end{array}$ & $\begin{array}{l}\text { Switzer- } \\
\text { land }\end{array}$ & $\begin{array}{c}\text { Analytical } \\
\text { study }\end{array}$ & $\begin{array}{c}\text { Models to estimate } \\
\text { the COVID-19 impact } \\
\text { from china to other } \\
\text { countries. }\end{array}$ & $\begin{array}{l}\text { The data } \\
\text { source is } \\
\text { the national } \\
\text { and provin- } \\
\text { cial heath } \\
\text { commission. } \\
\text { For interna- } \\
\text { tional data, } \\
\text { the source is } \\
\text { WHO. }\end{array}$ & $\begin{array}{c}\text { Continuing containment measures will } \\
\text { reduce the rapid growth of COVID-19 } \\
\text { drastically. } \\
\text { A strong correlation between the initial } \\
\text { and total confirmed numbers of infected } \\
\text { cases and travel index quantifying the } \\
\text { mobility between provinces. }\end{array}$ \\
\hline Yang Z., et al. [4] & $\begin{array}{c}\text { Distinguish- } \\
\text { ing COVID-19 } \\
\text { from influenza } \\
\text { pneumonia in } \\
\text { the early stage } \\
\text { through CT } \\
\text { imaging and } \\
\text { clinical features }\end{array}$ & China & $\begin{array}{l}\text { Clinical } \\
\text { study }\end{array}$ & $\begin{array}{l}\text { Differentiate between } \\
\text { COVID-19 and Influ- } \\
\text { enza. }\end{array}$ & $\begin{array}{c}73 \text { consecu- } \\
\text { tive patients } \\
\text { confirmed } \\
\text { with severe } \\
\text { acute respira- } \\
\text { tory syn- } \\
\text { drome. }\end{array}$ & $\begin{array}{c}\text { The crazy paving is crucial for differen- } \\
\text { tiation between the cases. } \\
\text { The bronchial wall thickening was } \\
\text { proved to be not significantly differ- } \\
\text { ent between influenza and COVID-19 } \\
\text { pneumonia. } \\
\text { To evaluate the significant statistical } \\
\text { difference of CT imaging and clinical fea- } \\
\text { tures between COVID-19 and influenza } \\
\text { pneumonia. }\end{array}$ \\
\hline
\end{tabular}

Table 1: Summary of the reviewed articles. 


\section{Conflict of Interest}

This is to confirm that the authors and the institution have no financial or conflicts of interest.

\section{Funding}

This research did not receive any specific grant from funding agencies in the public, commercial, or not-for-profit sectors.

\section{Acknowledgments}

The authors would like to thank the Radiography and Medical Imaging senior students and staff (Bushra khamis Al qutaiti, Nouf Al bloushi, Amani Omar Alseiari, Mariam Mohammed Alseari, Hanadi Mohsen Bagail, Rauda Musabbeh Alsaedi, Fatima Khamis Al Raisi, Sahana Kotian and Jerald Paul) for providing help during the research.

\section{Bibliography}

1. "Coronaviruses Fact Sheet" (2020).

2. Backer JA., et al. "Incubation Period of 2019 Novel Coronavirus (2019- NCoV) Infections among Travellers from Wuhan, China, 2028 January 2020". Euro Surveillance 25.5 (2020): 2000062.

3. Ashari MA., et al. "Strategies for Radiology Departments in Handling the COVID-19 Pandemic". Diagnostic and Interventional Radiology (Ankara, Turkey) 26.4 (2020): 296-300.

4. Yang Z., et al. "Distinguishing COVID-19 from Influenza Pneumonia in the Early Stage through CT Imaging and Clinical Features". medRxiv 4.17 (2020): 20061242.

5. "Similarities and Differences between Flu and COVID-19" (2020).

6. Yin Z., et al. "A Comparison of Clinical and Chest CT Findings in Patients with Influenza A (H1N1) Virus Infection and Coronavirus Disease (COVID-19)". American Journal of Roentgenology 215.5 (2020): 1065-1071.

7. Huang Z., et al. "The Battle Against Coronavirus Disease 2019 (COVID-19): Emergency Management and Infection Control in a Radiology Department". Journal of the American College of Radiology 17.6 (2020): 710-716.

8. Goh Y., et al. "Operational Strategies to Prevent Coronavirus Disease 2019 (COVID-19) Spread in Radiology: Experience
From a Singapore Radiology Department After Severe Acute Respiratory Syndrome". Journal of the American College of Radiology 17.6 (2020): 717-723.

9. Ding J., et al. "Prevention and Control Measures in Radiology Department for COVID-19". European Radiology 30.7 (2020): 3603-3608.

10. Khan SH., et al. "Coronavirus Disease Analysis Using Chest Xray Images and a Novel Deep Convolutional Neural Network". preprint (2020).

11. Cozzi D., et al. "Chest X-ray in New Coronavirus Disease 2019 (COVID-19) Infection: Findings and Correlation with Clinical Outcome”. Radiology Medica 125.8 (2020): 730-737.

12. Gogna A., et al. "Diagnostic Ultrasound Services During the Coronavirus Disease (COVID-19) Pandemic". American Journal of Roentgenology 215.5 (2020): 1130-1135.

13. "Obstetric ultrasound examinations during the COVID-19 pandemic". Society of Radiographers (2020).

14. Shen X., et al. "Coronavirus Disease 2019: MRI Examination Procedures and Infection Prevention and Protection". Annals of Translational Medicine's 8.17 (2020): 1074-1074.

15. "Radiology Departments Preparedness Plan for COVID-19" (2020).

16. Qu J., et al. "Infection Control for CT Equipment and Radiographers' Personal Protection during the Coronavirus Disease (COVID-19) Outbreak in China". American Journal of Roentgenology 215.4 (2020): 940-944.

17. Zhao S., et al. "Anesthetic Management of Patients with COVID -19 Infections during Emergency Procedures". Journal of Cardiothoracic and Vascular Anesthesia 34.5 (2020): 1125-1131.

18. An P., et al. "Management Strategy of Novel Coronavirus (COVID-19) Pneumonia in the Radiology Department: A Chinese Experience". Diagnostic and Interventional Radiology 26.3 (2020): 200-203.

19. Basha MM., et al. "Radiology Department Preparedness for COVID-19: Radiology Scientific Expert Review Panel". Radiology 296.2 (2020): E106-E112. 
20. Liang Y., et al. "Screening for Chinese Medical Staff Mental Health by SDS and SAS during the Outbreak of COVID-19". Journal of Psychosomatic Research 133 (2020): 110102.

21. Chaudhry FB and Raza S. "COVID-19: Frontline Experience at a Tertiary Care Hospital in UK". Journal of Global Health 10.1 (2020): 10.010356.

22. Ertl Wagner BB., et al. "Preparedness for the COVID-19 Pandemic in a Tertiary Pediatric Radiology Department". Pediatric Radiology 50.8 (2020): 1059-1068.

23. Pan W., et al. "Mental State of Central Sterile Supply Department Staff during COVID-19 Epidemic and CART Analysis". BMC Health Services Research 20.1 (2020): 1006.

24. "Things to Know about the COVID-19 Pandemic" (2020).

25. Ierardi AM., et al. "How to Handle a COVID-19 Patient in the Angiographic Suite". CardioVascular and Interventional Radiology 43.6 (2020): 820-826.

26. Alvin MD., et al. "The Impact of COVID-19 on Radiology Trainees". Radiology 296.2 (2020): 246-248.

27. Cárdenas Camarena L., et al. "Elective Surgery during SARSCov-2/COVID-19 Pandemic: Safety Protocols with Literature Review". Plastic and Reconstructive Surgery-Global Open 8.6 (2020): e2973.

28. Dashraath P., et al. "Coronavirus Disease 2019 (COVID-19) Pandemic and Pregnancy". American Journal of Obstetrics and Gynecology 222.6 (2020): 521-531.

29. Davenport MS., et al. "ACR Statement on Safe Resumption of Routine Radiology Care During the Coronavirus Disease 2019 (COVID-19) Pandemic". Journal of the American College of Radiology 17.7 (2020): 839-844.

30. "Interim Guidance" (2020).

31. Jakobsson J., et al. "Physical Activity During the Coronavirus (COVID-19) Pandemic: Prevention of a Decline in Metabolic and Immunological Functions". Frontiers in Sports and Active Living 2 (2020): 57.

32. Kooraki S., et al. "Coronavirus (COVID-19) Outbreak: What the Department of Radiology Should Know". Journal of the Ameri- can College of Radiology 17.4 (2020): 447-451.

33. LaHue SC., et al. "Collaborative Delirium Prevention in the Age of COVID-19". Journal of the American Geriatrics Society 68.5 (2020): 947-949.

34. Lv M., et al. "Chest Computed Tomography for the Diagnosis of Patients with Coronavirus Disease 2019 (COVID-19): A Rapid Review and Meta-Analysis". Annals of Translational Medicine's 8.10 (2020): 622-622.

35. Jin JM., et al. "Gender Differences in Patients With COVID-19: Focus on Severity and Mortality". Frontiers in Public Health 8 (2020): 152.

36. Mirza SK., et al. "Microbiology for Radiologists: How to Minimize Infection Transmission in the Radiology Department". Radiographics 35.4 (2015): 1231-1244.

37. Rab S., et al. "Face Masks Are New Normal after COVID-19 Pandemic". Diabetes and Metabolic Syndrome 14.6 (2020): 16171619.

38. Raptis CA., et al. "Chest CT and Coronavirus Disease (COVID-19): A Critical Review of the Literature to Date". American Journal of Roentgenology 215.4 (2020): 839-842.

39. Wang Z., et al. "Survival Analysis of Hospital Length of Stay of Novel Coronavirus (COVID-19) Pneumonia Patients in Sichuan, China". medRxiv (2020): 2020.04.07.20057299.

40. “Situation Report-82 HIGHLIGHTS” (2020).

41. “COVID-19 strategy update” (2020).

42. Wu K., et al. "Generalized Logistic Growth Modeling of the COVID-19 Outbreak: Comparing the Dynamics in the 29 Provinces in China and in the Rest of the World". Nonlinear Dynamics 101.3 (2020): 1561-1581.

\section{Volume 4 Issue 8 August 2021 (C) All rights are reserved by Mustafa Khaled Alhasan and Mohamed Hasaneen.}

